\title{
A Framework for Assessing Impacts of Wild Meat Hunting Practices in the Tropics
}

\author{
Andy D. M. Dobson ${ }^{1}$ (D) - E. J. Milner-Gulland ${ }^{2} \cdot$ Daniel J. Ingram $^{3} \cdot$ Aidan Keane $^{1}$
}

Published online: 8 June 2019

(C) The Author(s) 2019

\begin{abstract}
Terrestrial wildlife is being hunted for consumption by humans in the tropics at an unprecedented rate, and the often unsustainable nature of this harvest has profound implications not only for biodiversity and ecosystem function, but also for human livelihoods. Whilst the nature and impacts of this practice have been studied in numerous contexts and localities, a comprehensive treatment of the social, economic, and environmental determinants of both hunter decision-making and hunting outcomes has been lacking. In this review we discuss influences of hunting methods and effort on the types of animals caught, the efficiency of harvest, and the implications of these factors for sustainability. We highlight gaps in current understanding, and identify the most important data requirements. Our approach provides a framework for the design of future studies into wild meat hunting and its impacts, promoting the efficient targeting of priority areas of research.
\end{abstract}

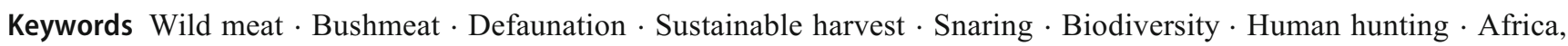
Amazonia, Southeast Asia

\section{Introduction}

The overhunting of wild animals for sale and subsequent human consumption is a major threat to biodiversity in the tropics (Milner-Gulland et al. 2003; Ripple et al. 2016; BenitezLopez et al. 2017), and has direct impacts on human nutrition and livelihoods (Nasi et al. 2011; Cawthorn and Hoffman 2015), as well as indirect impacts on ecosystem function (e.g., Vanthomme et al. 2010; Effiom et al. 2013). Estimates of wildlife offtake for 2010 in the Amazon and Congo basins approximate 1.3 million and 4.5 million tonnes, respectively (Nasi et al. 2011), and where they have been calculated,

Electronic supplementary material The online version of this article (https://doi.org/10.1007/s10745-019-0075-6) contains supplementary material, which is available to authorized users.

Andy D. M. Dobson

andrew.dobson@ed.ac.uk

1 School of GeoSciences, University of Edinburgh, Edinburgh EH9 $3 F F, U K$

2 Department of Zoology, University of Oxford, Oxford OX1 3PS, UK

3 Centre for Biodiversity and Environment Research, University College London, Gower Street, London WC1E 6BT, UK offtake indicators show a rising trend (Ingram et al. 2015). The threats posed by unsustainable harvesting on this scale may be most acute in southeast Asia, where hunting is driven not only by demand for meat but also by lucrative markets for a huge range of wildlife products, and where impacts are exacerbated by globally unmatched rates of deforestation (Harrison et al. 2016).

Conservation scientists study hunting to quantify its ecological impacts and contributions to livelihoods, estimate its sustainability, and predict how it might respond to changing economic, environmental, and social conditions. An extensive body of field-based research has demonstrated the ecological impacts of hunting, typically involving 'hunter-follows' to estimate the efficiency of different methods (e.g., Noss 1998; Kümpel et al. 2008; Coad et al. 2013), whilst survey data at a range of spatial scales have identified influences of economic status, market forces, and armed conflict on hunter behaviour (e.g., Brashares et al. 2004, 2011; Wilkie et al. 2005; Nackoney et al. 2014; McNamara et al. 2016). Models have been used to extrapolate these results, for example predicting impacts of economic changes on hunting sustainability and human livelihoods (Milner-Gulland and Leader-Williams 1992; Damania et al. 2005; Conrad and Lopes 2017).

Significant challenges remain, however. The factors that could influence hunting pressure - including, but not limited 
to, consumer demand, poverty, governance, civil unrest, and cultural change - are numerous and inter-related (Lindsey et al. 2013; Cawthorn and Hoffman 2015), and many of the links between drivers and outcomes are still to be elucidated. In particular, the mechanisms by which external drivers influence hunter behaviour, and hence hunting practices, remain under-studied. This is unsurprising given that illegal hunting is a sensitive topic, so can rarely be addressed by direct methods (Gavin et al. 2010).

Interventions aimed at reducing the prevalence of hunting can also (or merely alternatively) affect method choice (e.g., prompting a switch from more detectable methods such as gun hunting to less detectable ones such as snaring). It can also affect the locations of hunting areas (e.g., by deterring hunters from entering protected areas or shifting them to less patrolled areas). These changes might go unnoticed by existing monitoring protocols as their outcomes might be apparent across different spatial and temporal scales to the intervention itself (Wu 2009; Sodhi et al. 2011). The potential for unintended consequences such as these can be minimised by a better $a$ priori understanding of hunting systems. Therefore, our objective in this paper is to guide researchers aiming to study human hunting systems by (a) providing a basic framework for considering the set of factors likely to influence hunting behaviour, (b) summarising current understanding of these factors and the linkages between them, and (c) identifying outstanding questions and knowledge-gaps that ought to be prioritised for future study. The literature is focussed primarily on the hunting of larger terrestrial animals in Africa, Amazonia, and southeast Asia.
The paper is split into two main sections, covering the methods (e.g., equipment types) and intensity (e.g., temporal and spatial distributions of effort) of hunting, respectively. We argue that this is a useful way to conceptually divide hunting practices; both are influenced by numerous external drivers (social, environmental, economic), but in distinct ways and with different implications. However, both aspects must be considered in order to evaluate the impacts of hunting behaviour on wildlife populations and the ways in which they might respond to change. They may also interact in important ways for example, the relationship between offtake and time spent hunting is very different for gun- and snare-hunters. The contents of these sections are organised around a framework for conceptualising the links among environment, hunter behaviour, and hunting offtake (Fig. 1). We conclude with a summary that includes key challenges and recommendations.

\section{Hunting Methods}

We discuss the factors that influence a hunter's choice of hunting method, and the implications of that choice in terms of offtake. In many cases these decisions will be more or less imposed (rather than merely influenced) by social and economic conditions, but the implications for wildlife are the same.

\section{Hunting Methods and their Determinants}

Hunting methods - encompassing both the equipment used and the manner in which they are typically employed - can be

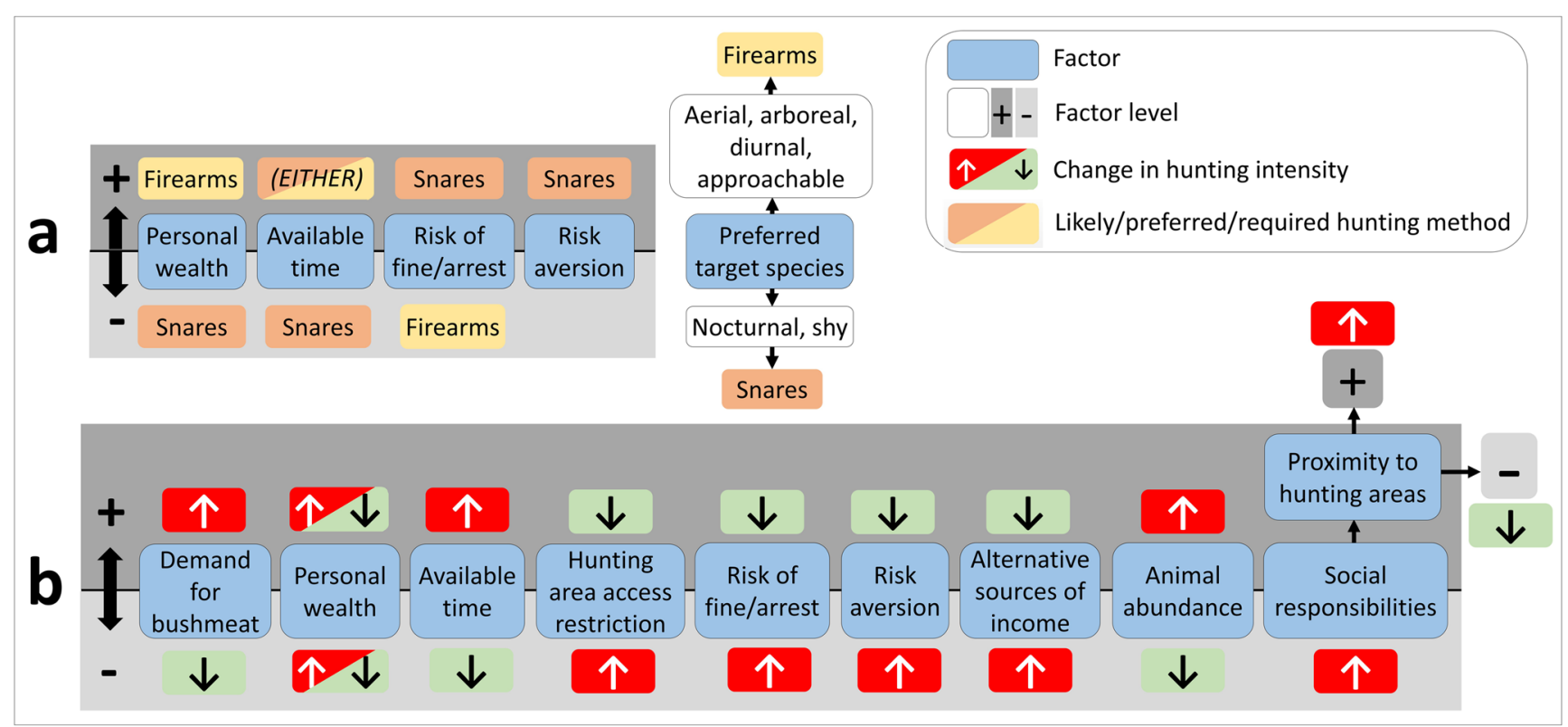

Fig. 1 Hunting activity necessarily follows from decisions made by individual hunters. An understanding of the factors that influence those decisions will help researchers to plan research and to develop effective intervention strategies. We split decisions into two types: those regarding methods used (a) and those regarding intensity (b) 
usefully split into categories of 'active' (e.g., shooting) and 'passive' (e.g., snaring). We describe the most commonly used methods, and discuss the circumstances under which each might be favoured and the implications for the individual hunter.

A snare is a noose that tightens around a body part of an animal and holds it until the hunter returns. Snares are typically left unsupervised and checked periodically. Despite frequently being illegal (see below), snaring can be an attractive means of obtaining meat and/or income, largely due to the low economic barrier to entry, especially when compared with gun-hunting (Kümpel et al. 2010; McNamara et al. 2016). For example, in Quangnam Province, Vietnam, a kilogram of muntjac (Muntiacus truongsonensis) meat would cover the cost of 20 snares (MacMillan and Nguyen 2014). Indeed, the free availability of metal cable may be one of the key drivers determining the abundance of snaring (Walters et al. 2015); most of the 84,396 snares removed over eight years from the Savé Valley Conservancy in Kenya were thought to have been fashioned from wire taken from the perimeter fence (Lindsey et al. 2011). However, whilst a set snare can theoretically remain effective for several months, older snares have lower capture rates than newer ones (Coad 2007; Kümpel et al. 2009), probably due to wire corrosion and (where applicable) loss of tension in the branch used to tighten the noose (H. Ibbett, pers. obs.).

Firearms have played a major role in the intensification of the wild meat trade throughout the tropics, largely replacing more primitive projectile weapons such as bows, spears, and blowpipes (Alvard 1995; Stearman 2000; Fa and Brown 2009; Luskin et al. 2014). Exceptions include countries where firearm laws are strict, such as Indonesia and Vietnam (Luskin et al. 2014; Harrison et al. 2016), and communities living under firearm prohibitions in protected areas (PAs) (e.g., Manu National Park, Peru; Shepard et al. 2012). For example, in Equatorial Guinea the government began to remove firearms from the civilian population in 1974; in one village of 200-300 people on Bioko island, 25 shotguns were owned prior to 1974 , falling to just one by 1986, before rising again to five by 1990 (Butynski and Koster 1994). Gun hunting remained rare in the country into the 2000s (Kümpel et al. 2009), partly as a result of a ban imposed on the Bubi ethnic group following a rebellion in 1998 (Vega et al. 2013), but shotgun hunting is common enough now to threaten primate populations in the non-Bubi parts of the island (Cronin et al. 2016).

There are two basic categories of hunting firearm - shotguns and rifles - which differ in the number of projectiles that are used for each shot. Shotguns are usually loaded with a large number of small projectiles (pellets) that spread when they leave the barrel, allowing moving targets to be hit; rifles fire a single projectile (bullet) which retains accuracy and power for greater distances than a shotgun (Heard 2008). Modern rifles and shotguns are loaded from the breech - the proximal end of the barrel - but some hunters use the olderstyle 'muzzle-loading' muskets, in which a charge of gunpowder is poured into the distal end (muzzle) of the barrel, followed by the projectile (Madhusudan and Karanth 2002; Martin et al. 2013). These guns are relatively primitive but still capable of killing the largest animal species, such as hippos and elephants (Brown and Marks 2007).

Standard firearms are relatively expensive - sufficient to exclude some hunters altogether (Nasi et al. 2011; Sirén and Wilkie 2014) - but locally made alternatives are not uncommon in the tropics (Barboza et al. 2011; Paudel 2012; Gardner and Davies 2014). In 2005, a locally produced shotgun could be purchased in Cameroon for between $6 \%$ and $21 \%$ of the price of an imported weapon (Nchanji 2005). A firearm may be a one-off purchase, meaning that its use is relatively unaffected by economic change, but ammunition for modern weapons is often expensive; for Baka hunters in Yasuoka's (2006) study in Cameroon, a single rifle cartridge cost six times more than the meat from a duiker carcass. As a result, many hunters in the tropics reload their own cartridges with locally produced gunpowder (Brown and Marks 2007; Vieira et al. 2015), or revert to muzzle-loaders when ammunition prices increase (Sirén and Wilkie 2014), though using 'loose' powder (as opposed to cartridges) increases the likelihood of misfiring in humid environments, and these weapons are likely to be more dangerous for the user and less efficient as hunting tools (Carpaneto and Fusari 2000; Brown and Marks 2007).

Snaring requires a relatively low degree of basic skill (Kümpel 2006; Wilcox and Nambu 2007; Hayashi 2008), though there does appear to be an influence of experience on snare-hunting success (Kümpel 2006; Coad 2007). In Kümpel's (2006) study in Equatorial Guinea, one individual trapper was exceptionally prolific, with a rate of capture per trap more than five times higher than the average for the other hunters at the site, a difference not attributable to higher effort.

Gun hunting has the disadvantage of noise; gunshots may scare away wildlife (Alvard 1993; Hodgkinson 2009) and alert ranger patrols to the presence of the hunter in PAs; (Madhusudan and Karanth 2002; Gandiwa 2011). No study has yet attempted to quantify the relative detection probabilities for gun- and snare-hunters (it would require detailed spatial data on the hunters detected by patrols, as well as their actual distributions), nor whether the two types of hunter perceive this risk differently, but it is a potentially important factor for hunting motivations in PAs. Evidence for hunters switching between methods in response to changes in perceived detection risk is currently only anecdotal; Rogan et al. (2017) speculated that the desire to avoid detection may explain the recently reported practice of hunting large animals on horseback or motorbikes without firearms in Tanzania and Botswana (see also Kiffner et al. 2014; Eustace 2017), and hypothesised that an increase in law enforcement activities 
would further promote secretive methods of hunting. Knapp (2012) suggested that the threat of detection by patrols had caused a shift towards night-time hunting in the western Serengeti, though such behaviour might equally reflect a need for increased efficiency in the face of declining wildlife abundance. Conversely, whilst gun-hunters are presumably more conspicuous than snare-hunters, they are also perceived to be more dangerous by ranger patrols (Ford 2005; Henson et al. 2016; Moreto 2016), who may consequently avoid confrontations for fear of injury or death (Holmern et al. 2007).

Hunting methods also differ in their versatility. Damp conditions can hinder a gun-hunter; muzzle-loaders will not fire when the powder is wet, and even powder within shotgun cartridges can become damp and unusable (Hames 1979; Noss 1995). Snares are more resilient, though metal cable will eventually rust. Guns - particularly muzzle-loaders and locally made shotguns - also pose a risk to the user; weak metalwork and/or over-loading with powder can cause a potentially fatal explosion in the breech (Carpaneto and Fusari 2000; Brown and Marks 2007).

Physical effort invested in snaring may be considerable, and limit snare-hunting to those who have few demands on their time. Where wildlife is depleted, snaring involves travelling long distances at frequent intervals, with attendant costs in terms of energy, economic opportunity, and social capital. All other things being equal, a complete snare hunt entails at least twice the travel of a gun hunt (or else an extended stay in the hunting area, imposing opportunity costs), since the snares must be left for a period of time. Coad (2007) argued that time spent in the forest took snare-hunters away from family responsibilities, including the requirement to "protect their family (wives) from other men"; moving into the forest to stay in temporary hunting camps was seen as "slightly mad."

\section{Capture Efficiency}

The durability and simplicity of metal cable has allowed snaring to be conducted on industrial scales (Gray et al. 2018); in Fa and Garcia Yuste's (2001) study site, an average of 25.9 hunters per month accounted for 107,945,772 snare-nights over a 16-month period. Snares are found across the tropics, though they are far less commonly mentioned in wild meat literature from the Neotropics than from the Old World. The passive nature of snaring also means that it can easily be integrated into daily routines; indeed snares are often set in the margins of crop fields, granting the hunter at least a nonzero chance of capturing an animal when he or she is engaged in other activities such as farm work (Sato 1983), or even gunhunting (Kümpel 2006; Rist et al. 2008). In one sense, snaring is extremely efficient, given that the snare is operational even while the hunter is absent, but quantifying efficiency is problematic.
Efficiency can be described in basic terms as harvest divided by effort, but the latter is difficult to quantify in a uniform manner. Effort has been characterised in a variety of ways in the literature, though usually as some form of time or distance measure; for snare-hunters, the number of snares is also frequently used (see Rist et al. 2008 for a thorough treatment). This lack of consistency could hamper attempts to draw general conclusions about hunting sustainability, since direct comparisons are difficult. However, whilst a degree of standardisation might be useful, it is probably not meaningful to try to directly compare efficiencies between passive and active forms of hunting, even if efforts could be compared. 'Time' is an obvious but problematic metric because the inputs are continuous for gun-hunters and sporadic for snarehunters, yet totalling the separate inputs of the latter would be inappropriate given that the length of time a snare is left in the forest has an important bearing on offtake. For example, a common measure of effort is 'snare-nights,' the product of the number of snares and the number of nights for which they are left set. However, there are two means by which snarechecking interval (which is not the same as the total time during which the snare is active, because not all unchecked snares will be inactive) influences the likelihood that a set snare will yield an edible carcass. Firstly, a snare occupied by a caught animal is a missed opportunity to capture another (Rist et al. 2008), and a snare may be sprung without capturing anything (Sato 1983), rendering it useless until the hunter returns. Secondly, captured animals left in snares are vulnerable to rotting and to scavenging by predators (Hawkes et al. 1991; Noss 1998; Wilkie and Carpenter 1999; Kümpel 2006). A simple model of a snare-hunter operating 20 snares reveals up to a three-fold difference in useable harvest size for snares checked daily, rather than once, over a thirty-day snaring period, taking already-closed snares and rotting rates into account (Box 1). The measure 'snare-nights' is therefore uninformative without the checking interval. Note that in this example, the relationship between harvest and effort is nonlinear; however, a hypothetical hunter who sets 20 additional snares in a separate area - instead of doubling the checking interval in the first area - might achieve a linear relationship, and therefore greater efficiency (assuming no dispersal of wildlife between areas).

Distance measures likewise lack comparability, since distance travelled might broadly correspond to animal encounter rate for gun-hunters, but for snare-hunters there may not be a linear relationship between distance travelled and number of snares set, and it is the latter that influences capture success.

\section{Selectivity}

Snares are often described as indiscriminate or non-selective (e.g., Lindsey et al. 2011; MacMillan and Nguyen 2014; 
Becker et al. 2013), and unintended bycatch must be included in any ecological assessment of snare-hunting impacts. However, several factors may allow hunters to dictate the size, and even species, of animal caught. Snares are predominantly set on the ground but may also (much more rarely) be set in trees to catch birds and arboreal mammals (Bulmer 1968; Noss 1995; Golden 2009). Deliberate spatial placement - both fine-scale (e.g., outside burrows, along animal tracks, near fruit trees or water holes, arboreal vs terrestrial) and largerscale (e.g., habitat type) - can change the likelihood of capturing particular taxa, and the properties of the snare itself are also influential, including height above the ground, loop diameter, wire thickness, snare design (leg or neck), and pressure required to trigger the snare (Colell et al. 1994; Noss 1998; Fa and Garcia Yuste 2001; Kümpel 2006; Rist et al. 2008; Pangau-Adam et al. 2012). Coad (2007) asked snarehunters in Gabon which species each individual snare was designed to capture, and compared the actual catch with that expected if catch proportions were driven by relative species abundances. Animal trails were attributed to one of six species, which was the species subsequently caught on $51 \%$ of occasions $(N=1028)$, indicating that hunters were able to use snare placement to influence the species they caught. Rist et al. (2008) also found that capture probabilities of four of the five most commonly trapped species in their Equatorial Guinea site were significantly associated with trap type. Duikers, for example, were exclusively caught in leg traps, whilst small carnivores were captured equally in leg and neck traps. Varying the thickness of wire strands used to make the noose is a further means of species selectivity. Snare-hunters in southeastern Cameroon used double strands for targeting medium-sized duikers (Cephalophus spp.), and single strands for the smaller blue duiker (Philantomba monticola); the larger animals could reportedly break through the single-strand nooses (Yasuoka et al. 2015). In snares set on animal paths in Gabon, Coad (2007) found a significant relationship between the identity of the animal assumed by hunters to have made the path and the number of strands used for the noose.

Whilst snare-hunters do have some control over the species they target, they are nonetheless primarily limited to terrestrial taxa; snares may be placed in trees (e.g., Golden 2009), but this may involve considerable extra effort, as well as the risk of injury. Guns allow more practical hunting of arboreal mammals as well as birds, and the gun-hunter also has a greater degree of influence over individual targets, such that selectivity could theoretically be limited only by their identification skills, though different firearms have different effective ranges and capabilities. Low-powered, small-calibre weapons limit the hunter to small-bodied animals; rifles (as opposed to shotguns) restrict hunters to stationary targets (Table A2, online Supporting Information). The largest animals, such as buffalo, elephant, or rhino, typically require large-calibre rifles (though see Stiles 2011 for accounts of elephants hunted with relatively small-calibre assault rifles). Hunting these potentially dangerous animals has attendant risks for the hunter (Martin et al. 2013; Eustace 2017), though beyond anecdotal accounts it is not known how hunters weight the relative costs and benefits of hunting these species. The risks are not confined to gun-hunters, however; snare-hunters in the western Serengeti reported conflict with lions who were attracted to dying herbivores in snares (Knapp 2012).

The extent to which a gun-hunter can target individual species may be mediated by animal behaviour as well as by hunter skill, and this factor can interact with the choice of method to determine selectivity (Holmern et al. 2006; Mysterud 2011). For example, species differ in the ease with which they may be approached (Altmann 1958; Blumstein et al. 2003; Fernández-Juricic et al. 2004); the distance at which an animal typically flees a human observer - the 'flight initiation distance' - will determine how often it will be within range of a projectile weapon, and may change in response to disturbance, including hunting pressure (Marealle et al. 2010; Tarakini et al. 2014; Kiffner et al. 2014; Muposhi et al. 2016). Yasuoka et al. (2015) hypothesised that blue duiker were more vulnerable to gun-hunters than Peter's duiker (C. callipygus) because they were less wary of humans, responded to hunters' bleating calls, and tended to 'freeze' when caught in a flashlight beam. This freezing behaviour is widely reported for a range of species, and in some cases the retina reflects the light in a conspicuous manner (Willcox and Nambu 2007; Newton et al. 2008; van Vliet and Nasi 2008; Gandiwa 2011). As well as facilitating targeting of certain species, modern flashlights have widened opportunities for active hunting for at least two other reasons. Firstly, they allow hunting to take place during otherwise 'vacant' hours (Dounias 2016), and during times when detection by ranger patrols is less likely (Nyahongo et al. 2005; Holmern et al. 2007). Secondly, they allow pursuit-hunters to target nocturnal species that otherwise could only be caught in snares (Coad 2007). This means that hunting with torches at night is potentially much easier than daytime hunting, allowing less skilled hunters to be successful, and further raising the efficiency of more skilled hunters (Wilkie and Carpenter 1999; Hodgkinson 2009; Barboza et al. 2011). It is not clear whether hunters currently lacking flashlights (or those for whom batteries are particularly expensive; Parry et al. 2009) would increase hunting effort if they had access to them, or whether they would simply shift the timing of hunting in order to concentrate on other economic activities during daylight hours. However, a switch to nocturnal hunting is unlikely to be cost-free; moving in the forest at night exposes humans to elevated risk of wildlife attack, especially where elephants are present (Sitati and Ipara 2012; Acharya et al. 2016), and working at night limits the scope for daytime activities.

The selectivity of hunting methods has mixed implications for sustainability. Where hunting is selective, individual 
species are not necessarily depleted in proportion to their relative availability (Lu 2010; Constantino 2015). Deliberate 'switching' behaviour, whereby hunters focus attention away from rarer species and toward more abundant ones, can allow sustainable harvest even under heavy offtake pressure (Cowlishaw et al. 2005; Kümpel et al. 2009). Given the potential for selective targeting with snares, even hunting systems dominated by snaring may display this sort of dynamic response. However, some hunters may continue to target rare species, especially if they are particularly valuable (Wilkie et al. 2011; Young et al. 2016), and the presence of abundant, low-value species may effectively subsidise the more opportunistic harvesting of much rarer species that might have been able to recover had hunting become economically non-viable (Wilkie et al. 2011; Branch et al. 2013). The effects of hunting on populations may also be intra-specific (e.g., Holmern et al. 2006), with effects dependent upon the social organisation of the species (Milner et al. 2007; Mysterud 2011). For example, males may be more prone to encountering snares if they range further than females, or to being targets for gun-hunting if they are less cryptic in behaviour or colouration. It is also feasible that (inadvertent) selection for larger individuals could be achieved in some species by the number of wire strands used to make the noose. However, whilst hunters may target certain species or individuals, intentionally or not, there is no evidence in the literature concerning the relative impacts of intra-specific selectivity by hunting method, or the potential effects on population viability.

\section{Hunting Intensity}

The proportion of an individual's time spent hunting is dictated largely by their economic situation (Fig. 1). Hunting often serves as an economic buffer in times of hardship (Nasi et al. 2008; Cawthorn and Hoffman 2015), though it can also be a primary source of income (Milner-Gulland et al. 2003; PangauAdam et al. 2012; Alexander et al. 2015). The relative importance of wild meat - and hence the benefit accrued from hunting - can vary temporally; hunting is more likely to occur when crop harvests have been poor, during lulls in agricultural activity (Shively 1997; Brashares et al. 2011; Wilfred and MacColl 2015), and when wildlife abundance is particularly high, such as annual migrations of ungulates in East Africa (Holmern et al. 2007; Lindsey et al. 2011). In general, the complex relationships between a person's socioeconomic situation and their engagement in hunting are under-studied. The social status of a hunter may influence their willingness to hunt for profit (Coad 2007), and there appears to be much variation in this regard, with hunting associated with both prestige (e.g., Hawkes et al. 2001; Brown and Marks 2007) and poverty (e.g., Kümpel et al. 2010), or viewed with ambivalence (e.g., Hodgkinson 2009). The likelihood of a given individual 'dropping out' of hunting in order to pursue other economic activities may also be non-random, with younger or less efficient hunters doing so more readily, meaning that a drop in the number of adult males hunting in a community may not produce an equivalent reduction in offtake (Coad et al. 2013).

Unfortunately, robust, quantitative data on the trade-offs made by potential hunters who have alternative economic options are scarce. This is largely due to the sensitivity around hunting, necessitating indirect sampling methods such as choice experiments and the 'randomised response' and 'unmatched count' techniques, which are limited in the type of questions that can be asked, can be misunderstood by respondents, and inevitably produce 'noisy' data requiring large sample sizes (St. John et al. 2010; Nuno and St John 2015). There is also uncertainty over the extent to which stated preferences correlate with actual behaviour (Murphy et al. 2005; St. John et al. 2014). Finally, the results are typically nuanced and difficult to generalise. For example, two choiceexperiment studies in Tanzania indicated that the donation of livestock would reduce incentives for hunting (Moro et al. 2013; Nielsen et al. 2014). However, in Moro et al.'s (2013) survey of villagers in an area where hunting is common, wealthier respondents valued hunting less than poorer ones, while among a sample of 325 active wild meat traders, the willingness to give up hunting was inversely related to household wealth (Nielsen et al. 2014).

In PAs, an obvious barrier to undertaking frequent hunting trips is the presence of ranger patrols, and the perceived threat of sanctions is likely to influence hunter behaviour to some degree (Keane et al. 2008; St. John et al. 2015). Illegal hunting activity is often concentrated near PA borders and/or points of easy access, for example in East Africa (Wato et al. 2006; Watson et al. 2013; Kimanzi et al. 2015), Cambodia (O'Kelly 2013), Paraguay (Hill et al. 1997), and Brazil (Kauano et al. 2017), suggesting that risk-avoidance has an influence on hunting movements within PAs. However, several authors have also reported spatial correlations between snare density and wildlife density (Nyahongo et al. 2005; Watson et al. 2013), including aggregations of snares at saltlicks, waterholes, lake edges, and rivers (Becker et al. 2013; Critchlow et al. 2015; Kimanzi et al. 2015). Indeed, the deterrent effect of patrolling is difficult to assess, and few studies are able to demonstrate a positive impact (Dobson et al. 2018, though see Moore et al. 2018). Hunting in PAs is common in many countries (Nyahongo et al. 2005; Duffy et al. 2016; Kauano et al. 2017; Rogan et al. 2017; Castilho et al. 2018), which suggests that the protection status of an area is not necessarily a good indicator of likely hunting pressure.

Legal considerations aside, hunters in different regions will experience varying degrees of freedom over where they may hunt, dictating the diversity and abundance of species available (and hence the harvest size; Coad 2007; Smith 2008; Table 1). Many studies describe village hunting territories that 
are more or less strictly respected, including in Central and West Africa (Muchaal and Ngandjui 1999; Fa and Garcia Yuste 2001; Hayashi 2008), the Neotropics (Peres and Nascimento 2006; Smith 2008), Arunachal Pradesh, India (Singh et al. 2014), Papua New Guinea (Mack and West 2005), and Papua, Indonesia (Pattiselanno 2008; PangauAdam et al. 2012), though these territories may be dynamic and delineated in part by wildlife distribution and sociocultural factors as well as physical boundaries (Constantino 2015). Villagers from the Philippine province of Palawan reported that wild animals were viewed as an "open-access resource to which few restrictions applied"; this was an area where almost no commercial hunting took place but wild meat was nonetheless an important component of household economies (Shively 1997). However, the extent to which spatial rules are respected by hunters may depend upon the history of governance (Duffy et al. 2016); for example, successive colonial and national administrations in Gabon have rearranged traditional land use allocation systems, resulting in a looser and more ill-defined sense of land ownership and hunting rules (Coad 2007; Walters et al. 2015). In Ecuador, where subsistence hunting is legalised under some circumstances (and selling wild meat is always illegal), hunting rights are theoretically determined by ethnicity, but enforcement either of hunting behaviour or sale of wild meat is highly inconsistent, and hence does little to limit the trade (Espinosa et al. 2014; Cummins et al. 2015).

Benefits in terms of harvest must outweigh the costs of travel, which may be direct (time, physical effort, fuel) or indirect (increased exposure to law enforcement patrols; Hofer et al. 2000), but it is not clear whether there are absolute limits to the distances that hunters will travel from settlements to reach wildlife-rich areas (and such limits would presumably be context-specific). Road building to provide access to resources such as timber, oil, and minerals also exposes forests to greatly increased hunting pressure (Abernethy et al. 2013; Espinosa et al. 2014; Lessmann et al. 2016). Roads not only facilitate hunting, but also create links between rural populations of hunters and urban markets, potentially changing the economies of formerly subsistence-only communities by altering the cost-benefit balance in favour of commercial hunting (Espinosa et al. 2018). In a review of hunting in Central Africa, Abernethy et al. (2013) stated that village hunters typically travel less than $10 \mathrm{~km}$ from the village on daily trips, and an ongoing database pertaining to hunting of wild terrestrial species across the globe provides a mean per-village hunting territory of $301 \mathrm{~km}^{2}$ ( $\mathrm{SE} \pm 78 \mathrm{~km}^{2}, n=66$ villages) for this region, which approximates a circle of radius $9.8 \mathrm{~km}$ (calculated based on Ingram et al. 2015). However, where hunters set up temporary forest camps, hunting may occur at distances up to $50 \mathrm{~km}$ from permanent settlements, allowing hunters to access relatively non-depleted areas without incurring daily transport costs (Hayashi 2008; Prado et al. 2012;
Abernethy et al. 2013; Van Vliet et al. 2014). The ability to leave permanent settlements for extended periods of time may therefore have a significant impact on an individual's opportunities for hunting and thus their potential response to altered economic circumstances.

Kümpel et al. (2009) found increasing snare density with distance from hunting camps in Equatorial Guinea (in direct contrast to the typical pattern of snare distribution in relation to settlements; Muchaal and Ngandjui 1999; Coad 2007), indicating a primary concern for per-snare harvest efficiency. However, at the same site, localised wildlife depletion did not cause hunters to move ever further afield, but instead to increase the average number of snares per hunter from 56 to 92 over a 13 year period (Kümpel 2006; Table 2), suggesting that although maximising yield was a major concern, the perceived travel cost was high, or at least that a threshold of acceptable travel distance existed. An alternative explanation is that the expected density of wildlife further into the forest was no higher, hence there would be relatively little to gain from the extra effort. Like snare-hunters in West Africa, pursuit hunters in the Neo-tropics have been reported to concentrate activities relatively close to settlements (within $10 \mathrm{~km}$ ), and to achieve greater efficiency at more distant sites (Sirén et al. 2004; Smith 2008).

\section{Knowledge Gaps and Future Directions}

Despite the large volume of literature devoted to hunting practices, our review has highlighted several key knowledge gaps where future research could be usefully targeted (summarised in Box 2).

From a conservation perspective, perhaps the largest gap in current understanding concerns the behavioural responses of hunters to changing external conditions (e.g., the strategies adopted in response to large-scale economic, social, or ecological change), and the ways in which these changing external conditions interact with conservation interventions. Under altered economic circumstances, non-hunters may become hunters, and vice-versa, but there may also be more subtle switches between target species or hunting technologies and the role of hunting within the broader household economy. Despite case-specific insights, we lack the generalizable information on the decision-making process involved in these changes needed to move from description to prediction (contrast, for example, Moro et al. 2013 and Nielsen et al. 2014, discussed above). Models designed to predict hunting impacts have typically relied on the assumption of economic rationality in hunters or consumers (e.g., Damania et al. 2005; Rentsch and Damon 2013; Iwamura et al. 2014). This assumption may be a practical expedient, but there is increasing evidence that it fails to capture important aspects of reality 
(e.g., Rakotonarivo et al. 2017; Ponta et al. 2019). Knowledge of the discrepancy between economically optimal choices and actual behaviour would improve predictions of hunting offtakes under a given scenario. Experimental games and agent-based models (ABMs) are two promising tools for engaging with 'real' behaviour. Games offer an opportunity to test the rationality of human actors in realistic scenarios (Redpath et al. 2018), whilst ABMs have the flexibility to explore the implications of differences in individual strategies (DeAngelis and Grimm 2014).

Of crucial concern for conservationists is the impact of ranger patrols and other means of law enforcement on hunter behaviour, but whilst deterrence is almost assumed by default, evidence for a consistent effect is lacking (Dobson et al. 2018, but see Moore et al. 2018 for a convincing demonstration of reduced hunting activity as patrol effort increases). There is anecdotal evidence of hunters switching to less detectable and/ or risky modes of hunting when faced with the threat of arrest (Rogan et al. 2017), but hunters might also respond by displacing effort to new locations or targeting different species, and the extent and ultimate conservation impacts of this switching behaviour remain unknown. We do not yet know enough to make reliable predictions about the impacts of changes to any given law enforcement regime. Rangerderived data will require careful analysis to avoid the impacts of confounding variables (Keane et al. 2011; Dobson et al. 2018), and should ideally be accompanied by data from independent sources (e.g., concurrent household income surveys) in order to validate results by triangulation.

Other relative unknowns include individual-level determinants of hunting success, which alter the relative profitability, and hence economic attractiveness, of hunting. Snaring and shooting require different sets of skills, and the results of many studies imply that skill is an important factor in hunting success (e.g., Coad 2007; Kümpel et al. 2009). Understanding individual variation could allow conservationists to better design and target interventions (cf. Jones et al. 2018). However, the extent of this influence is currently unclear, and it could be mediated via numerous individual abilities, including snare construction, marksmanship, tracking and stalking animals, and the ability to anticipate the spatial distribution of animals. Koster et al.'s (2019) analysis of an extensive dataset from 1821 hunters across 40 sites worldwide shows that individual skill tends to peak between the ages of 30 and 35, but since 'skill' here is inferred by proxy from productivity, these data cannot, unfortunately, be used to unpick the relationship between these two variables. Future work could adopt longitudinal approaches (cf. Gray et al. 2015) in order to determine the most important determinants of individual variation in hunting ability and track how it changes over time as individuals learn or forget skills.

Research undertaken in this area should ideally be readily applicable to practical management action, and published in non-academic media or open-access journals (Fuller et al. 2014; Hogg et al. 2017) in order to prevent a gap emerging between academic and applied practice (Hogg et al. 2017; Taylor et al. 2017; Britt et al. 2018). Prioritisation of the questions listed here should be conducted in collaboration with onthe-ground practitioners (Tables 1 and 2).

\section{Summary}

Where hunting is an economic activity, choices about the methods used and the proportion of an individual's time spent on the activity will be influenced by an array of external factors. Estimates of hunting sustainability must be made in the knowledge that hunter decisions are context-dependent and liable to change. Researchers aiming to predict how sustainability might change over time should first identify the relevant drivers of, and constraints on, hunter choice in their study system in order to demarcate the options available to the individual. This process requires an understanding of the characteristics of different modes of hunting.

Some very general patterns are evident: Snaring is almost universal because of its accessibility; snares also allow a hunter to maintain at least a non-zero chance of capturing animals whilst they are primarily engaged in other economic activities; hunting with firearms requires a greater investment in terms of time and money, and probably a higher threshold of skill. The choice of hunting method, which dictates prey selectivity and hunter efficiency (though not in a straightforward manner), depends upon available capital, other demands on time, and degree of physical competence; hunting effort may be dictated not only by economic concerns but by social and cultural constraints; and the selection of areas used for hunting, which determines the animal populations at risk, is the result of an interaction between the potential offtake, law enforcement pressure, and social determinants of accessibility. Researchers need an understanding of these determinants of hunting decision-making as well as their implications for offtake in order to predict future trajectories of hunting impact on wildlife. Much of this understanding can be found in the literature (e.g., Lindsey et al. 2013; Cawthorn and Hoffman 2015), but much remains under-studied (Box 2).

Limited funding for conservation means that the effectiveness of potential interventions should be quantified as far as possible in order to facilitate comparisons between alternative options, whilst appreciating that the spatial and temporal scopes of hunting practices and the actions undertaken to limit them may vary. For example, the benefit of ranger patrols that displace hunters cannot be assessed without taking into account impacts in areas to which hunters are displaced (requiring a broad spatial focus), whilst benefits of economic policies such as infrastructure investment, education, or microfinance could take many years to fully accrue (requiring broad 


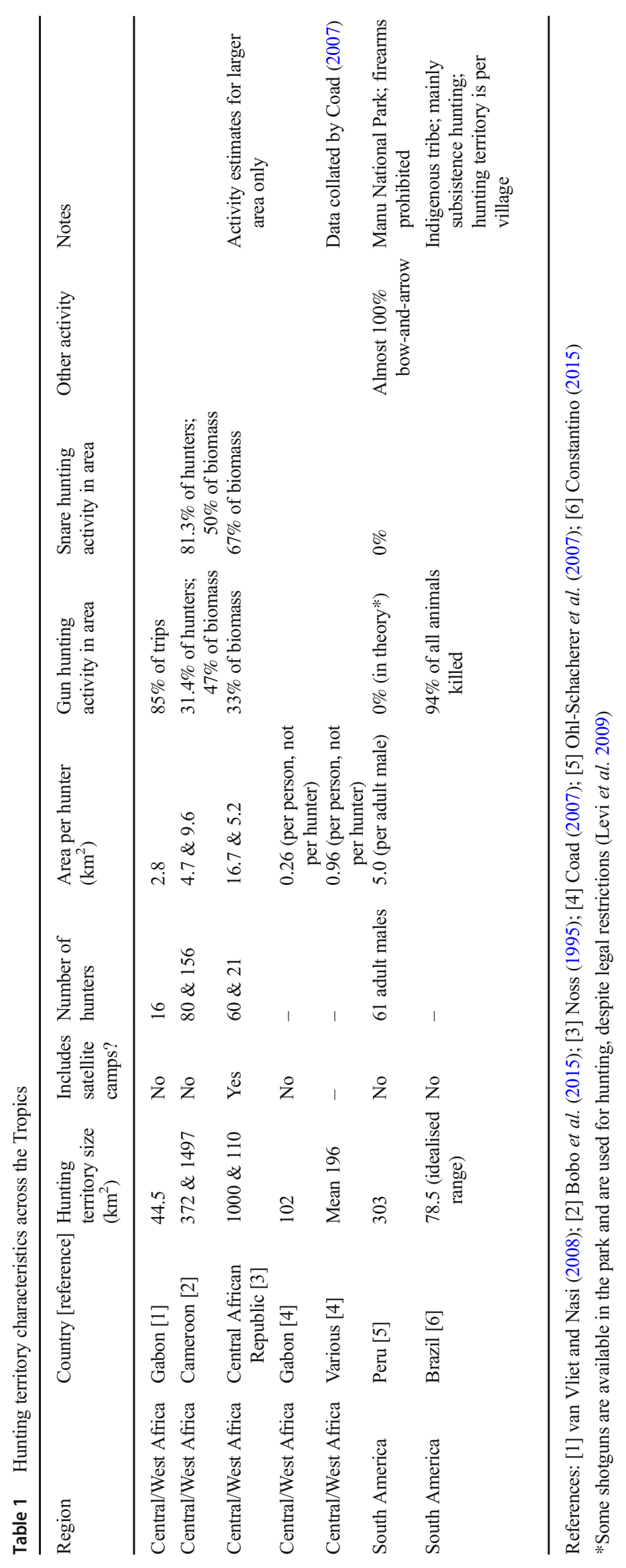




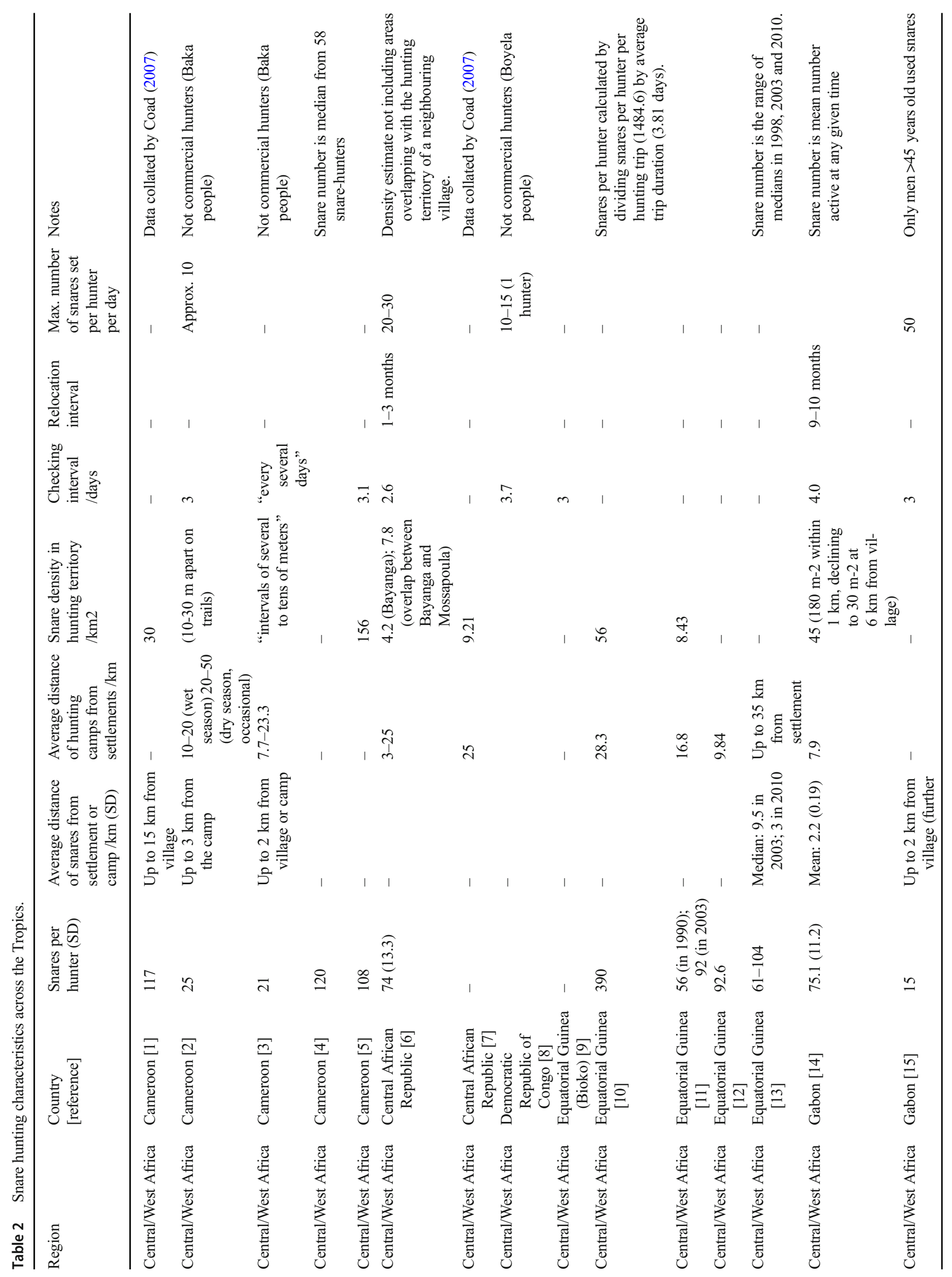


temporal focus; Ferraro and Pattanayak 2006). Studies of effectiveness must be designed in such a way as to encompass this variation.

Conservation management plans often focus heavily on law enforcement, but there is little direct evidence for the threat of fines or incarceration altering hunter behaviour (Leader-Williams et al. 1990; Moore et al. 2018). Another major issue in translating research findings into practical recommendations for conservation action is understanding the information gained in research studies about hunters' tradeoffs, especially the degree to which stated preferences translate into real behaviour. Finally, a more nuanced understanding of the factors driving individual hunters' decision-making will reduce the potential for unintended consequences from conservation interventions (Larrosa et al. 2016). For all of these questions, the extent of generalisability needs to be established. Studies of any given aspect of wild meat hunting tend to be geographically clustered, such that uncritical extrapolation of the results could lead to systematic errors (Taylor et al. 2015). A greater emphasis on comparative studies, using consistent approaches where possible, across widely differing contexts should be a future priority.

Compliance with Ethical Standards This study was funded by the Natural Environment Research Council [grant number NE/ N001370/1]

Conflict of Interest The authors declare that they have no conflict of interest.

Open Access This article is distributed under the terms of the Creative Commons Attribution 4.0 International License (http:// creativecommons.org/licenses/by/4.0/), which permits unrestricted use, distribution, and reproduction in any medium, provided you give appropriate credit to the original author(s) and the source, provide a link to the Creative Commons license, and indicate if changes were made.

\section{References}

Abernethy, K. A., Coad, L., Taylor, G., Lee, M. E., and Maisels, F. (2013). Extent and ecological consequences of hunting in central African rainforests in the twenty-first century. Phil. Trans. R. Soc. B. 368(1625): 20120303.

Acharya, K. P., Paudel, P. K., Neupane, P. R., and Köhl, M. (2016). Human-wildlife conflicts in Nepal: Patterns of human fatalities and injuries caused by large mammals. PLoS one 11(9): e0161717.

Akani, G. C., Petrozzi, F., Ebere, N., Dendi, D., Phil-Eze, P., Nioking, A., and Luiselli, L. (2015). Correlates of indigenous hunting techniques with wildlife trade in bushmeat markets of the Niger delta (Nigeria). Vie et Milieu-Life and Environment 65(3): 169-174.

Alexander, J. S., McNamara, J., Rowcliffe, J. M., Oppong, J., and MilnerGulland, E. J. (2015). The role of bushmeat in a West African agricultural landscape. Oryx 49(4): 643-651.

Altmann, M. (1958). The flight distance in free-ranging big game. Journal of Wildlife Management 22(2): 207-209. 
Alvard, M. S. (1993). Testing the "ecologically noble savage" hypothesis: Interspecific prey choice by Piro hunters of Amazonian Peru. Human Ecology 21(4): 355-387.

Alvard, M. (1995). Shotguns and sustainable hunting in the Neotropics. Oryx 29(1): 58-66.

Barboza, R. R. D., Mourão, J. S., Souto, W. M. S., and Alves, R. R. N. (2011). Knowledge and strategies of Armadillo (Dasypus novemcinctus L. 1758 and Euphractus sexcinctus L. 1758) hunters in the Sertão Paraibano, Paraíba state, NE Brazil. Bioremediation. Biodiversity and Bioavailability 5(special issue 1): 1-7.

Becker, M., McRobb, R., Watson, F., Droge, E., Kanyembo, B., Murdoch, J., and Kakumbi, C. (2013). Evaluating wire-snare poaching trends and the impacts of by-catch on elephants and large carnivores. Biological Conservation 158: 26-36.

Benitez-Lopez, A., Alkemade, R., Schipper, A. M., Ingram, D. J., Verweij, P. A., Eikelbloom, J. A. J., and Huijbregts, M. A. J. (2017). The impact of hunting on tropical mammal and bird populations. Science 356: 180-183.

Blumstein, D. T., Anthony, L. L., Harcourt, R., and Ross, G. (2003). Testing a key assumption of wildlife buffer zones: Is flight initiation distance a species-specific trait? Biological Conservation 110(1): 97-100.

Bobo, K. S., Obioha, E., Ngoufo, R., Jimoh, S., and Waltert, M. (2011). Managing Forest Wildlife for Human Livelihoods: A Multi-agent Systems Model to Assess Socio-economic and Ecological Sustainability. Abstracts from the International Research on Food Security, Natural Resource Management and Rural Development, Tropentag 2011.

Bobo, K. S., Kamgaing, T. O., Kamdoum, E. C., and Dzefack, Z. S. C. (2015). Bushmeat hunting in southeastern Cameroon: Magnitude and impact on duikers (Cephalophus spp.). African Study Monographs 51 (suppl: 119-141.

Branch, T. A., Lobo, A. S., and Purcell, S. W. (2013). Opportunistic exploitation: An overlooked pathway to extinction. Trends in ecology \& evolution 28(7): 409-413.

Brashares, J. S., Arcese, P., Sam, M. K., Coppolillo, P. B., Sinclair, A. R., and Balmford, A. (2004). Bushmeat hunting, wildlife declines, and fish supply in West Africa. Science 306(5699): 1180-1183.

Brashares, J. S., Golden, C. D., Weinbaum, K. Z., Barrett, C. B., and Okello, G. V. (2011). Economic and geographic drivers of wildlife consumption in rural Africa. Proceedings of the National Academy of Sciences 108(34): 13931-13936.

Britt, M., Haworth, S. E., Johnson, J. B., Martchenko, D., and Shafer, A. B. (2018). The importance of non-academic coauthors in bridging the conservation genetics gap. Biological Conservation 218: 118123.

Brown, T., and Marks, S. (2007). Livelihoods, hunting and the game meat trade in northern Zambia. In Davies, G., and Brown, D. (eds.), Bushmeat and livelihoods, Blackwell, Oxford, UK, pp. 92-106.

Bulmer, R. (1968). The strategies of hunting in New Guinea. Oceania 38(4): 302-318.

Butynski, T. M., and Koster, S. H. (1994). Distribution and conservation status of primates in Bioko Island, Equatorial Guinea. Biodiversity \& Conservation 3(9): 893-909.

Carpaneto, G. M., and Fusari, A. (2000). Subsistence hunting and bushmeat exploitation in Central-Western Tanzania. Biodiversity \& Conservation 9: 1571-1585.

Castilho, L. C., De Vleeschouwer, K. M., Milner-Gulland, E. J., and Schiavetti, A. (2018). Attitudes and behaviors of rural residents toward different motivations for hunting and deforestation in protected areas of the northeastern Atlantic Forest, Brazil. Tropical Conservation Science 11. https://doi.org/10.1177/ 1940082917753507.

Cawthorn, D. M., and Hoffman, L. C. (2015). The bushmeat and food security nexus: A global account of the contributions, conundrums and ethical collisions. Food Research International 76: 906-925.
Coad, L. (2007). Bushmeat hunting in Gabon: Socio-economics and hunter behaviour. In $\mathrm{PhD}$ thesis, University of Cambridge and Imperial College, London.

Coad, L., Schleicher, J., Milner-Gulland, E. J., Marthews, T. R., Starkey, M., Manica, A., Balmford, A., Mbombe, W., Diop Bineni, T. R., and Abernethy, K. A. (2013). Social and ecological change over a decade in a village hunting system, Central Gabon. Conservation Biology 27(2): 270-280.

Colell, M., Maté, C., and Fa, J. E. (1994). Hunting among Moka Bubis in Bioko: Dynamics of faunal exploitation at the village level. Biodiversity and Conservation 3: 939-950.

Conrad, J. M., and Lopes, A. A. (2017). Poaching and the dynamics of a protected species. Resource and Energy Economics 48: 55-67.

Constantino, P. D. A. L. (2015). Dynamics of hunting territories and prey distribution in Amazonian indigenous lands. Applied Geography 56: $222-231$.

Cowlishaw, G., Mendelson, S., and Rowcliffe, J. M. (2005). Evidence for post-depletion sustainability in a mature bushmeat market. Journal of applied ecology 42(3): 460-468.

Critchlow, R., Plumptre, A. J., Driciru, M., Rwetsiba, A., Stokes, E. J., Tumwesigye, C., Wanyama, F., and Beale, C. M. (2015). Spatiotemporal trends of illegal activities from ranger-collected data in a Ugandan national park. Conservation Biology 29: 1458-1470.

Cronin, D. T., Riaco, C., Linder, J. M., Bergl, R. A., Gonder, M. K., O'Connor, M. P., and Hearn, G. W. (2016). Impact of gun-hunting on monkey species and implications for primate conservation on Bioko Island, Equatorial Guinea. Biological Conservation 197: 180-189.

Cummins, I., Pinedo-Vasquez, M., Barnard, A. and Nasi, R. (2015). Agouti on the wedding menu: Bushmeat harvest, consumption and trade in a post-frontier region of the Ecuadorian Amazon (Vol. 138). CIFOR. https://doi.org/10.17528/cifor/005730.

Damania, R., Milner-Gulland, E. J., and Crookes, D. J. (2005). A bioeconomic analysis of bushmeat hunting. Proceedings of the Royal Society of London B: Biological Sciences 272(1560): 259 266.

DeAngelis, D. L., and Grimm, V. (2014). Individual-based models in ecology after four decades. F1000prime reports 6: 39 .

Dethier M. (1996). Etude chasse villageoise. Report to the ECOFAC project: Brussels, Belgium.

Dobson, A. D. M., Milner-Gulland, E. J., Beale, C. M., Ibbett, H., and Keane, A. (2018). Detecting deterrence from patrol data. Conservation Biology. https://doi.org/10.1111/cobi.13222.

Dounias, E. (2016). From subsistence to commercial hunting: Technical shift in Cynegetic practices among southern Cameroon Forest dwellers during the $20^{\text {th }}$ century. Ecology \& Society 21(1): 23 .

Duffy, R., St John, F. A., Büscher, B., and Brockington, D. (2016). Toward a new understanding of the links between poverty and illegal wildlife hunting. Conservation Biology 30(1): 14-22.

Effiom, E. O., Nuñez-Iturri, G., Smith, H. G., Ottosson, U., and Olsson, O. (2013). Bushmeat hunting changes regeneration of African rainforests. Proceedings of the Royal Society of London B: Biological Sciences 280(1759): 20130246.

Espinosa, S., Branch, L. C., and Cueva, R. (2014). Road development and the geography of hunting by an amazonian indigenous group: Consequences for wildlife conservation. PLoS ONE 9(12): e114916. https://doi.org/10.1371/journal.pone.0114916.

Espinosa, S., Celis, G., and Branch, L. C. (2018). When roads appear jaguars decline: Increased access to an Amazonian wilderness area reduces potential for jaguar conservation. PLoS ONE 13(1): e0189740. https://doi.org/10.1371/journal.pone.0189740.

Eustace, A. (2017). My chat with a poacher in Western Serengeti. Animal Conservation 20(6): 481-482.

Fa, J. E., and Brown, D. (2009). Impacts of hunting on mammals in African tropical moist forests: A review and synthesis. Mammal Review 39(4): 231-264. 
Fa, J. E., and Garcia Yuste, J. E. (2001). Commercial bushmeat hunting in the Monte Mitra forests, Equatorial Guinea: Extent and impact. Animal Biodiversity and Conservation 24: 31-52.

Fernández-Juricic, E., Vaca, R., and Schroeder, N. (2004). Spatial and temporal responses of forest birds to human approaches in a protected area and implications for two management strategies. Biological Conservation 117(4): 407-416.

Ferraro, P. J., and Pattanayak, S. K. (2006). Money for nothing? A call for empirical evaluation of biodiversity conservation investments. PLoS Biology 4(4): e105.

Ford, A. (2005). An evaluation of wildlife monitoring and anti-poaching activities. In MSc thesis: Imperial College London.

Fuller, R. A., Lee, J. R., and Watson, J. E. (2014). Achieving open access to conservation science. Conservation Biology 28(6): 1550-1557.

Gandiwa, E. (2011). Preliminary assessment of illegal hunting by communities adjacent to the northern Gonarezhou National Park, Zimbabwe. Tropical Conservation Science 4(4): 445-467.

Gardner, C. J., and Davies, Z. G. (2014). Rural bushmeat consumption within multiple-use protected areas: Qualitative evidence from Southwest Madagascar. Human Ecology 42(1): 21-34.

Gavin, M. C., Solomon, J. N., and Blank, S. G. (2010). Measuring and monitoring illegal use of natural resources. Conservation Biology 24(1): 89-100.

Gill, D. J., Fa, J. E., Rowcliffe, J. M., and Kümpel, N. F. (2012). Drivers of change in hunter offtake and hunting strategies in Sendje, Equatorial Guinea. Conservation Biology 26(6): 1052-1060.

Golden, C. D. (2009). Bushmeat hunting and use in the Makira Forest, northeastern Madagascar: A conservation and livelihoods issue. Oryx 43(3): 386-392.

Gray, C. L., Bozigar, M., and Bilsborrow, R. E. (2015). Declining use of wild resources by indigenous peoples of the Ecuadorian Amazon. Biological Conservation 182: 270-277.

Gray, T. N., Hughes, A. C., Laurance, W. F., Long, B., Lynam, A. J., O'Kelly, H., Ripple, W. J., Seng, T., Scotson, L., and Wilkinson, N. M. (2018). The wildlife snaring crisis: An insidious and pervasive threat to biodiversity in Southeast Asia. Biodiversity and Conservation 27(4): 1031-1037.

Hames, R. B. (1979). A comparison of the efficiencies of the shotgun and the Bow in Neotropical Forest hunting. Human Ecology 7(3): 219252.

Harrison, R. D., Sreekar, R., Brodie, J .F., Brook, S., Luskin, M., O'Kelly, H., Rao, M., Scheffers, B., and Velho, N. (2016). Impacts of hunting on tropical forests in Southeast Asia. Conservation Biology 30(5): 972-981.

Hawkes, K., O'Connell, J. F., and Blurton Jones, N. G. (1991). Hunting income patterns among the Hadza: Big game, common goods, foraging goals and the evolution of the human diet. Philosophical Transactions of the Royal Society of London, B 334: 243-251.

Hawkes, K., O'Connell, J. F., Blurton Jones, N. G., Bell, D., Bird, R., Bird, D., Hames, R., Ivey, P., Judge, D., Kazankov, A., and Minnegal, M. (2001). Hunting and nuclear families: Some lessons from the Hadza about mens work. Current Anthropology 42(5): 681-709.

Hayashi, K. (2008). Hunting activities in Forest camps among the Baka Hunter-gatherers of southeastern Cameroon. African Study Monographs 29(2): 73-92.

Heard, BJ (2008). Handbook of Firearms and Ballistics: Examining and Interpreting Forensic Evidence, Second Edition. John Wiley \& Sons, Ltd, Chichester, UK.

Henson, D. W., Malpas, R. C., and D'Udine, F. A. C. (2016). Wildlife Law Enforcement in Sub-Saharan African Protected Areas: A Review of Best Practices. Occasional Paper of the IUCN Species Survival Commission No. 58. Cambridge, UK and Gland, Switzerland: IUCN.

Hill, K., Padwe, J., Bejyvagi, C., Bepurangi, A., Jakugi, F., Tykuarangi, R., and Tykuarangi, T. (1997). Impact of hunting on large vertebrates in the Mbaracayu reserve, Paraguay. Conservation Biology 11(6): 1339-1353.

Hodgkinson, C. (2009). Tourists, gorillas and guns: Integrating conservation and development in the Central African Republic. PhD thesis, University College, London.

Hofer, H., Campbell, K. L., East, M. L., and Huish, S. A. (2000). Modeling the spatial distribution of the economic costs and benefits of illegal game meat hunting in the Serengeti. Natural Resource Modeling 13(1): 151-177.

Hogg, C. J., Grueber, C. E., Pemberton, D., Fox, S., Lee, A. V., Ivy, J. A., and Belov, K. (2017). "Devil Tools \& Tech": A synergy of conservation research and management practice. Conservation Letters 10(1): 133-138.

Holmern, T., Mkama, S., Muya, J., and Røskaft, E. (2006). Intraspecific prey choice of bushmeat hunters outside the Serengeti National Park, Tanzania: A preliminary analysis. African Zoology 41(1): $81-87$.

Holmern, T., Muya, J., and Røskaft, E. (2007). Local law enforcement and illegal bushmeat hunting outside the Serengeti National Park, Tanzania. Environmental Conservation 34(1): 55-63.

Ingram, D. J., Coad, L., Collen, B., Kümpel, N. F., Breuer, T., Fa, J. E., Gill, D. J. C., Maisels, F., Schleicher, J., Stokes, E. J., Taylor, G., and Scharlemann, J. P. W. (2015). Indicators for wild animal offtake: Methods and case study for African mammals and birds. Ecology and Society 20(3): 40.

Iwamura, T., Lambin, E. F., Silvius, K. M., Luzar, J. B., and Fragoso, J. M. V. (2014). Agent-based modeling of hunting and subsistence agriculture on indigenous lands: Understanding interactions between social and ecological systems. Environmental Modelling \& Software 58: 109-127.

Jones, S., Keane, A., St John, F., Vickery, J., and Papworth, S. (2018). Audience segmentation to improve the targeting of hunters by conservation interventions around Gola forest. Liberia. Conservation Biology. https://doi.org/10.1111/cobi.13275.

Kauano, É. E., Silva, J. M., and Michalski, F. (2017). Illegal use of natural resources in federal protected areas of the Brazilian Amazon. PeerJ 5: e3902.

Keane, A., Jones, J. P., Edwards-Jones, G., and Milner-Gulland, E. J. (2008). The sleeping policeman: Understanding issues of enforcement and compliance in conservation. Animal conservation 11(2): $75-82$.

Keane, A., Jones, J. P. G., and Milner-Gulland, E. J. (2011). Encounter data in resource management and ecology: Pitfalls and possibilities. Journal of Applied Ecology 48(5): 1164-1173.

Kiffner, C., Kioko, J., Kissui, B., Painter, C., Serota, M., White, C., and Yager, P. (2014). Interspecific variation in large mammal responses to human observers along a conservation gradient with variable hunting pressure. Animal conservation 17(6): 603-612.

Kimanzi, J. K., Sanderson, R. A., Rushton, S. P., and Mugo, M. J. (2015). Spatial distribution of snares in Ruma National Park, Kenya, with implications for management of the roan antelope Hippotragus equinuslangheldi and other wildlife. Oryx 49(2): 295-302.

Knapp, E. J. (2012). Why poaching pays: A summary of risks and benefits illegal hunters face in Western Serengeti, Tanzania. Tropical Conservation Science 5(4): 434-445.

Koster, J., McElreath, R., Hill, K., Yu, D., Shepard, G., van Vliet, N., Gurven, M., Kaplan, H., Trumble, B., Bird, R.B. and Bird, D. (2019). The life history of human foraging: Cross-cultural and individual variation. bioRxiv 574483 .

Kümpel, N. F. (2006). Incentives for sustainable hunting of bushmeat in Rio muni, Equatorial Guinea. $\mathrm{PhD}$ thesis, Imperial College London and Institute of Zoology, London.

Kümpel, N. F., Milner-Gulland, E. J., Rowcliffe, J. M., and Cowlishaw, G. (2008). Impact of gun-hunting on diurnal primates in continental Equatorial Guinea. International Journal of Primatology 29(4): 1065-1082. 
Kümpel, N. F., Rowcliffe, J. M., Cowlishaw, G., and Milner-Gulland, E. J. (2009). Trapper profiles and strategies: Insights into sustainability from hunter behaviour. Animal Conservation 12(6): 531-539.

Kümpel, N. F., Milner-Gulland, E. J., Cowlishaw, G., and Rowcliffe, J. M. (2010). Incentives for hunting: The role of bushmeat in the household economy in rural Equatorial Guinea. Human Ecology 38(2): 251-264.

Larrosa, C., Carrasco, L. R., and Milner-Gulland, E. J. (2016). Unintended feedbacks: Challenges and opportunities for improving conservation effectiveness. Conservation Letters 9(5): 316-326.

Leader-Williams, N., Albon, S. D., and Berry, P. S. M. (1990). Illegal exploitation of black rhinoceros and elephant populations: Patterns of decline, law enforcement and patrol effort in Luangwa Valley, Zambia. Journal of Applied Ecology: 1055-1087.

Lessmann, J., Fajardo, J., Munoz, J., and Bonaccorso, E. (2016). Large expansion of oil industry in the Ecuadorian Amazon: Biodiversity vulnerability and conservation alternatives. Ecology and evolution 6(14): 4997-5012.

Levi, T., Shepard, G. H. Jr., Ohl-Schacherer, J., Peres, C. A., and Douglas, W. Y. (2009). Modelling the long-term sustainability of indigenous hunting in Manu National Park, Peru: Landscape-scale management implications for Amazonia. Journal of Applied Ecology 46(4): 804 814.

Lindsey, P. A., Romanach, S. S., Tambling, C. J., Chartier, K., and Groom, R. (2011). Ecological and financial impacts of illegal bushmeat trade in Zimbabwe. Oryx 45(1): 96-111.

Lindsey, P. A., Balme, G., Becker, M., Begg, C., Bento, C., Bocchino, C., Dickman, A., Diggle, R. W., Eves, H., Henschel, P., Lewis, D., et al (2013). The bushmeat trade in African savannas: Impacts, drivers, and possible solutions. Biological conservation 160: 80-96.

Lu, F. (2010). Patterns of indigenous resilience in the Amazon: A case study of Haorani hunting in Ecuador. Journal of Ecological Anthropology 14: 5-21.

Luskin, M. S., Christina, E. D., Kelley, L. C., and Potts, M. D. (2014). Modern hunting practices and wild meat trade in the oil palm plantation-dominated landscapes of Sumatra, Indonesia. Human Ecology 42(1): 35-45.

Mack, A. L., and West, P. (2005). Ten thousand Tonnes of small animals: Wildlife consumption in Papua New Guinea, a vital resource in need of management. Resource Management in Asia-Pacific Working Paper no. 61. Canberra: Resource management in Asia-pacific program.

MacMillan, D. C., and Nguyen, Q. A. (2014). Factors influencing the illegal harvest of wildlife by trapping and snaring among the Katu ethnic group in Vietnam. Oryx 48(2): 304-312.

Madhusudan, M. D., and Karanth, K. U. (2002). Local hunting and the conservation of large mammals in India. AMBIO: A Journal of the Human Environment 31(1): 49-54.

Marealle, W. N., Fossøy, F., Holmern, T., Stokke, B. G., and Røskaft, E. (2010). Does illegal hunting skew Serengeti wildlife sex ratios? Wildlife Biology 16(4): 419-429.

Martin, A., Caro, T., and Kiffner, C. (2013). Prey preferences of bushmeat hunters in an East African savannah ecosystem. European Journal of Wildlife Research 59(2): 137-145.

McNamara, J., Rowcliffe, M., Cowlishaw, G., Alexander, J. S., NtiamoaBaidu, Y., Brenya, A., and Milner-Gulland, E. J. (2016). Characterising wildlife trade market supply-demand dynamics. PloS one 11(9): e0162972.

Milner, J. M., Nilsen, E. B., and Andreassen, H. P. (2007). Demographic side effects of selective hunting in ungulates and carnivores. Conservation Biology 21(1): 36-47.

Milner-Gulland, E. J., and Leader-Williams, N. (1992). A model of incentives for the illegal exploitation of black rhinos and elephants: Poaching pays in Luangwa Valley, Zambia. Journal of Applied Ecology: 388-401.
Milner-Gulland, E. J., Bennett, E. L., and the SCB 2002 Annual Meeting Wild Meat Group (2003). Wild meat - The bigger picture. Trends in Ecology \& Evolution 18: 351-357.

Moore, J. F., Mulindahabi, F., Masozera, M. K., Nichols, J. D., Hines, J. E., Turikunkiko, E., and Oli, M. K. (2018). Are ranger patrols effective in reducing poaching-related threats within protected areas? Journal of Applied Ecology 55: 99-107.

Moreto, W. D. (2016). Occupational stress among law enforcement rangers: Insights from Uganda. Oryx 50(4): 646-654.

Moro, M., Fischer, A., Czajkowski, M., Brennan, D., Lowassa, A., Naiman, L. C., and Hanley, N. (2013). An investigation using the choice experiment method into options for reducing illegal bushmeat hunting in western Serengeti. Conservation Letters 6(1): $37-45$.

Muchaal, P. K., and Ngandjui, G. (1999). Impact of village hunting on wildlife populations in the western Dja reserve, Cameroon. Conservation Biology 13: 385-396.

Muposhi, V. K., Gandiwa, E., Makuza, S. M., and Bartels, P. (2016). Trophy hunting and perceived risk in closed ecosystems: Flight behaviour of three gregarious African ungulates in a semi-arid tropical savanna. Austral Ecology 41(7): 809-818.

Murphy, J. J., Allen, P. G., Stevens, T. H., and Weatherhead, D. (2005). A meta-analysis of hypothetical bias in stated preference valuation. Environmental and Resource Economics 30(3): 313-325.

Mysterud, A. (2011). Selective harvesting of large mammals: How often does it result in directional selection? Journal of Applied Ecology 48(4): 827-834.

Nackoney, J., Molinario, G., Potapov, P., Turubanova, S., Hansen, M. C., and Furuichi, T. (2014). Impacts of civil conflict on primary forest habitat in northern Democratic Republic of the Congo 1990-2010. Biological Conservation 170: 321-328.

Nasi, R., Brown, D., Wilkie, D., Bennett, E., Tutin, C., Van Tol, G., and Christophersen, T. (2008). Conservation and use of wildlife-based resources: The bushmeat crisis. Secretariat of the convention on biological diversity, Montreal and Center for International Forestry Research (CIFOR), Bogor Technical Series 50.

Nasi, R., Taber, A., and van Vliet, N. (2011). Empty forests, empty stomachs? Bushmeat and livelihoods in the Congo and Amazon basins. International Forestry Review 13(3): 355-368.

Nchanji, A. C. (2005). Elephant-poaching weapons and new experiences from the Banyang-Mbo wildlife sanctuary. Cameroon. Pachyderm 39: $33-42$.

Newton, P., Nguyen, T. V., Roberton, S., and Bell, D. (2008). Pangolins in peril: Using local hunters' knowledge to conserve elusive species in Vietnam. Endangered Species Research 6: 41-53.

Ngnegueu, P. R., and Fotso, R. C. (1996). Chasse villagoise et consequences pour la conservation de la biodiversite dans la reserve de biosphere du Dja. ECOFAC: Yaounde.

Nielsen, M. R., Jacobsen, J. B., and Thorsen, B. J. (2014). Factors determining the choice of hunting and trading bushmeat in the Kilombero Valley, Tanzania. Conservation Biology 28(2): 382-391.

Noss, A. J. (1995). Duikers, cables and nets: a cultural ecology of hunting in the central African forest. PhD Thesis: University of Florida.

Noss, A. J. (1998). The impacts of cable snare hunting on wildlife populations in the forests of the Central African Republic. Conservation Biology 12(2): 390-398.

Nuno, A., and St John, F. A. (2015). How to ask sensitive questions in conservation: A review of specialized questioning techniques. Biological Conservation 189: 5-15.

Nyahongo, J. W., East, M. L., Mturi, F. A., and Hofer, H. (2005). Benefits and costs of illegal grazing and hunting in the Serengeti ecosystem. Environmental Conservation 32(4): 326-332.

Ohl-Schacherer, J., Shepard, G. H., Kaplan, H., Peres, C. A., Levi, T., and Yu, D. W. (2007). The sustainability of subsistence hunting by Matsigenka native communities in Manu National Park, Peru. Conservation Biology 21(5): 1174-1185. 
O'Kelly, H. (2013). Monitoring conservation threats, interventions and impacts on wildlife in a Cambodian tropical Forest. $\mathrm{PhD}$ thesis, Imperial College, London.

Pangau-Adam, M., Noske, R., and Muehlenberg, M. (2012). Wildmeat or Bushmeat? Subsistence hunting and commercial harvesting in Papua (West New Guinea), Indonesia. Human Ecology 40: 611621.

Parry, L., Barlow, J., and Peres, C. A. (2009). Allocation of hunting effort by Amazonian smallholders: Implications for conserving wildlife in mixed-use landscapes. Biological Conservation 142(8): 1777-1786.

Pattiselanno, F. (2008). Man-wildlife interaction: Understanding the concept of conservation ethics in Papua. Tigerpaper 35(4): 10-12.

Paudel, P. K. (2012). Challenges to wildlife conservation posed by hunting in non-protected areas north of the Bardia National Park. In Kindlmann, P. (ed.), Himalayan biodiversity in the changing world, Springer, Dordrecht, pp. 177-196.

Peres, C. A., and Nascimento, H. (2006). Impact of game hunting by the Kayapó of southeastern Amazonia: Implications for wildlife conservation in tropical forest indigenous reserves. Biodiversity and Conservation 15: 2627-2653.

Ponta, N., Cornioley, T., Dray, A., van Vliet, N., Waeber, P. O., and Garcia, C. A. (2019). Hunting in times of change: Uncovering indigenous strategies in the Colombian Amazon using a role-playing game. Frontiers in Ecology and Evolution 7: 34. https://doi.org/10. 3389/fevo.

Prado, H. M., Forline, L. C., and Kipnis, R. (2012). Hunting practices among the Awá-Guajá: Towards a long-term analysis of sustainability in an Amazonian indigenous community. Boletim do Museu Paraense Emílio Goeldi. Ciências Humanas 7(2): 479-491.

Rakotonarivo, O. S., Jacobsen, J. B., Larsen, H. O., Jones, J. P. G., Nielsen, M. R., Ramamonjisoa, B. S., Mandimbiniaina, R. H., and Hockley, N. (2017). Qualitative and quantitative evidence on the true local welfare costs of forest conservation in Madagascar: Are discrete choice experiments a valid ex ante tool? World Development 94: 478-491.

Redpath, S. M., Keane, A., Andrén, H., Baynham-Herd, Z., Bunnefeld, N., Duthie, A. B., Frank, J., Garcia, C. A., Månsson, J., Nilsson, L., and Pollard, C. R. (2018). Games as tools to address conservation conflicts. Trends in Ecology \& Evolution 33(6): 415-426.

Rentsch, D., and Damon, A. (2013). Prices, poaching, and protein alternatives: An analysis of bushmeat consumption around Serengeti National Park, Tanzania. Ecological Economics 91: 1-9.

Ripple, W. J., Abernethy, K., Betts, M. G., Chapron, G., Dirzo, R., Galetti, M., Levi, T., Lindsey, P. A., Macdonald, D. W., Machovina, B., and Newsome, T. M. (2016). Bushmeat hunting and extinction risk to the world's mammals. Royal Society Open Science 3(10): 160498 .

Rist, J., Rowcliffe, M., Cowlishaw, G., and Milner-Gulland, E. J. (2008). Evaluating measures of hunting in a bushmeat system. Biological Conservation 141: 2086-2099.

Rogan, M. S., Lindsey, P. A., Tambling, C. J., Golabek, K. A., Chase, M. J., Collins, K., and McNutt, J. W. (2017). Illegal bushmeat hunters compete with predators and threaten wild herbivore populations in a global tourism hotspot. Biological Conservation 210: 233-242.

Sato, H. (1983). Hunting of the Boyela, slash-burn agriculturalists, in the Central Zaire forest. African Studies Monographs 4: 1-54.

Shepard, G. H., Levi, T., Neves, E. G., Peres, C. A., and Yu, D. W. (2012). Hunting in ancient and modern Amazonia: Rethinking sustainability. American Anthropologist 114(4): 652-667.

Shively, G. E. (1997). Poverty, technology, and wildlife hunting in Palawan. Environmental Conservation 24(1): 57-63.

Singh, R. K., Alves, R. N., and Ralen, O. (2014). Hunting of kebung (Ratufa bicolor) and other squirrel species from morang forest by the Adi tribe of Arunachal Pradesh, India: Biocultural conservation and livelihood dimensions. Regional environmental change 14(4): 1479-1490.
Sirén, A. H., and Wilkie, D. S. (2014). The effects of ammunition price on subsistence hunting in an Amazonian village. Oryx 50(1): 47-55.

Sirén, A., Hambäck, P., and Machoa, J. (2004). Including spatial heterogeneity and animal dispersal when evaluating hunting: A model analysis and an empirical assessment in an Amazonian community. Conservation Biology 18(5): 1315-1329.

Sitati, N. W., and Ipara, H. (2012). Indigenous ecological knowledge of a human-elephant interaction in Transmara district, Kenya: Implications for research and management. Advances in Anthropology 2(03): 107.

Smith, D. A. (2008). The spatial pattern of indigenous wildlife use in western Panama: Implications for conservation management. Biological Conservation 141: 925-937.

Sodhi, N. S., Butler, R., Laurance, W. F., and Gibson, L. (2011). Conservation successes at micro-, meso-and macroscales. Trends in Ecology \& Evolution 26(11): 585-594.

St. John, F. A. V., Edwards-Jones, G., Gibbons, J. M., and Jones, J. P. (2010). Testing novel methods for assessing rule breaking in conservation. Biological Conservation 143(4): 1025-1030.

St. John, F. A. V., Keane, A. M., Jones, J. P., and Milner-Gulland, E. J. (2014). Robust study design is as important on the social as it is on the ecological side of applied ecological research. Journal of Applied Ecology 51(6): 1479-1485.

St. John, F. A. V., Mai, C. H., and Pei, K. J. C. (2015). Evaluating deterrents of illegal behaviour in conservation: Carnivore killing in rural Taiwan. Biological Conservation 189: 86-94.

Stearman, A. M. A. (2000). Pound of flesh. Social change and modernization as factors in hunting sustainability among neotropical indigenous societies. In Robinson, J., and Bennett, E. (eds.), Hunting for sustainability in tropical forests, biology and resource series, Columbia University Press, New York, pp. 233-250.

Stiles, D. (2011). Elephant meat trade in Central Africa: Summary report. Gland, Switzerland, IUCN.

Tarakini, T., Crosmary, W. G., Fritz, H., and Mundy, P. (2014). Flight behavioural responses to sport hunting by two African herbivores. South African Journal of Wildlife Research 44(1): 76-83.

Taylor, G., Scharlemann, J. P. W., Rowcliffe, M., Kümpel, N., Harfoot, M. B. J., Fa, J. E., Melisch, R., Milner-Gulland, E. J., Bhagwat, S., Abernethy, K. A., and Ajonina, A. S. (2015). Synthesising bushmeat research effort in West and Central Africa: A new regional database. Biological Conservation 181: 199-205.

Taylor, H. R., Dussex, N., and van Heezik, Y. (2017). Bridging the conservation genetics gap by identifying barriers to implementation for conservation practitioners. Global Ecology and Conservation 10: 231-242.

van Vliet, N., and Nasi, R. (2008). Hunting for livelihood in Northeast Gabon: Patterns, evolution, and sustainability. Ecology and Society 13: 33.

van Vliet, N., Mesa, M. P. Q., Cruz-Antia, D., de Aquino, L. J. N., Moreno, J., and Nasi, R. (2014). The uncovered volumes of bushmeat commercialized in the Amazonian trifrontier between Colombia, Peru and Brazil. Ethnobiology and Conservation 3: 7. https://doi.org/10.15451/ec2014-11-3.7-1-11.

Vanthomme, H., Bellé, B., and Forget, P. M. (2010). Bushmeat hunting alters recruitment of large-seeded plant species in Central Africa. Biotropica 42(6): 672-679.

Vega, M. G., Carpinetti, B., Duarte, J., and Fa, J. E. (2013). Contrasts in livelihoods and protein intake between commercial and subsistence bushmeat hunters in two villages on Bioko Island, Equatorial Guinea. Conservation Biology 27(3): 576-587.

Vieira, M., von Muhlen, E. M., and Shepard, G. S. Jr. (2015). Participatory monitoring and management of subsistence hunting in the Piagaçu-Purus reserve, Brazil. Conservation \& Society 13: 254-264. 
Walters, G., Schleicher, J., Hymas, O., and Coad, L. (2015). Evolving hunting practices in Gabon: Lessons for community-based conservation interventions. Ecology and Society 20(4): 31.

Wato, Y. A., Wahungu, G. M., and Okello, M. M. (2006). Correlates of wildlife snaring patterns in Tsavo West National Park, Kenya. Biological conservation 132(4): 500-509.

Watson, F., Becker, M. S., McRobb, R., and Kanyembo, B. (2013). Spatial patterns of wire-snare poaching: Implications for community conservation in buffer zones around National Parks. Biological conservation 168: 1-9.

Wilfred, P., and MacColl, A. (2015). Local perspectives on factors influencing the extent of wildlife poaching for bushmeat in a game reserve, western Tanzania. International Journal of Conservation Science 6(1): 99-110.

Wilkie, D. S., and Carpenter, J. F. (1999). Bushmeat hunting in the Congo Basin: An assessment of impacts and options for mitigation. Biodiversity and Conservation 8: 927-955.

Wilkie, D. S., Starkey, M., Abernethy, K., Effa, E. N., Telfer, P., and Godoy, R. (2005). Role of prices and wealth in consumer demand for bushmeat in Gabon, Central Africa. Conservation biology 19(1): 268-274.

Wilkie, D. S., Bennett, E. L., Peres, C. A., and Cunningham, A. A. (2011). The empty forest revisited. Annals of the New York Academy of Sciences. 1223(1): 120-128.

Willcox, A. S., and Nambu, D. M. (2007). Wildlife hunting practices and bushmeat dynamics of the Banyangi and Mbo people of southwestern Cameroon. Biological Conservation 134(2): 251-261.
Wright, J. H., and Priston, N. E. (2010). Hunting and trapping in Lebialem division, Cameroon: Bushmeat harvesting practices and human reliance. Endangered Species Research 11: 1): 1-1):12.

$\mathrm{Wu}, \mathrm{T}$. (2009). Integrating biodiversity conservation with poverty reduction: A socioeconomic perspective. The Bulletin of the Ecological Society of America 90(1): 80-86.

Yasuoka, H. (2006). The sustainability of duiker (Cephalophus spp.) hunting for the Baka hunter-gatherers in southeastern Cameroon. African Study Monographs 33(suppl: 95-120.

Yasuoka, H., Hirai, M., Kamgaing, T. O., Dzefack, Z. S. C., Kamdoum, E. C., and Bobo, K. S. (2015). Changes in the composition of hunting catches in southeastern Cameroon: A promising approach for collaborative wildlife management between ecologists and local hunters. Ecology and Society 20(4): 25.

Young, H. S., McCauley, D. J., Galetti, M., and Dirzo, R. (2016). Patterns, causes, and consequences of anthropocene defaunation. Annual Review of Ecology, Evolution, and Systematics 47: 333358.

Publisher's Note Springer Nature remains neutral with regard to jurisdictional claims in published maps and institutional affiliations. 